\title{
SURFACE MORPHOLOGY OF BRAZILIAN MORACEAE POLLEN GRAINS
}

\author{
ORTRUD MONIKA BARTH
}

\section{RESUMO}

Superfícies dos grāos de pólen de 39 excicatas de 19 gêneros e 30 espécies foram examinadas por meio da microscopia eletrônica de varredura, a fim de obter esclarecimentos sobre o desenvolvi. mento da morfologia polínica nesta familia. Foi possível reconhecer os seguintes grupos polínicos: o de Ficus, o de Cecropia e o Dorstenia; todos os demais gêneros examinados pertencem a um mesmo grupo polínico que compreende diferentes subgrupos, correspondentes a uma variaçฐ̃o do número e da disposição de espiculos sobre a superfície dos grāos. Somente através de uma correlaçāo entre os aspectos das superfícies e a textura das exinas poderåo ser obtidas afinidades de parentesco para este grupo de espécies.

\section{ABSTRACT}

Pollen grain surfaces from 39 samples of 19 genera and 30 species were examined by scanning electron microscopy, in order to elucidate the development of pollen grain morphologies in this family. It was possible to recognize the Ficus, Cecropia and Dorstenia pollen groups. All other examined genera belong to the same pollen group, with several sub-groups, based upon variation in the number and arrangement of surface spinules or scabrae. Only through correlation of surface aspects with exine textures may one ascertain the affinities of this group of species.

\section{INTRODUCTION}

Pollen grains from Moraceae of different phytogeographic regions have been studied in several papers; older references are to be found in ERDTMAN (1952). Since then, in Brazil, MELHEM (1966) and SALGADO-LABOURIAU (1973) examined species from the Brazilian "cerrado" and BARTH et al. (1975) from anemophilous species; pollen grains of Dorstenia were examined by BARTH in CARAUTA et al. (1979) and of Cecropia by BARTH (1974).

Papers on pollen grains of Moraceae from other regions were elaborated as catalogues: NAIR \& SHARMA (1965) for India; STRAKA (1966) for Madagascar and the Mascarene Islands, TARNAVSCHI et al. (1967) for Romania; PALACIOS (1968) and RAMOS-ZAMORRA (1977) for Mexico; and HAMILTON (1976) for East Africa. Anemophilous species from Great Britain were studied by HYDE \& ADAMS (1958). Taxonomically, pollen grains of some genera were analysed by NIEZGODA \& NOWACZYK (1976) and PUNT \& EETGERINK (1982).
The grains commonly present a primitive exine structure, but it is possible to establish evolutionary relationships on the basis of variations among genera. BARTH (1976a) has made some observations on this matter using light microscopy (LM) with an optical resolution of ca. $0.1 \mu \mathrm{m}$. Yet some questions remain which require analysis of submicroscopic structures by electron microscopy. HAMILTON (1976), NIEZGODA \& NOWACZYK (1976), PUNT (1978) and PUNT \& EETGERINK (1982), for example, have examined pollen grains from numerous genera by scanning electron microscopy (SEM).

Our immediate purpose here is to examine by SEM the pollen grain surfaces of more species and genera, some of which have been previously studied by LM (BARTH, 1976a, b), so that the relationships among the genera and species may be revised and amplified.

\section{MATERIAL AND METHODS}

Material from the following Herbaria was used: Botanial Garden, Rio de Janeiro (RB); the Brazilian National Museum, Rio de Janeiro (R);

1 Instituto Oswaldo Cruz, Rio de Janeiro; Bolsista do CNPq. 

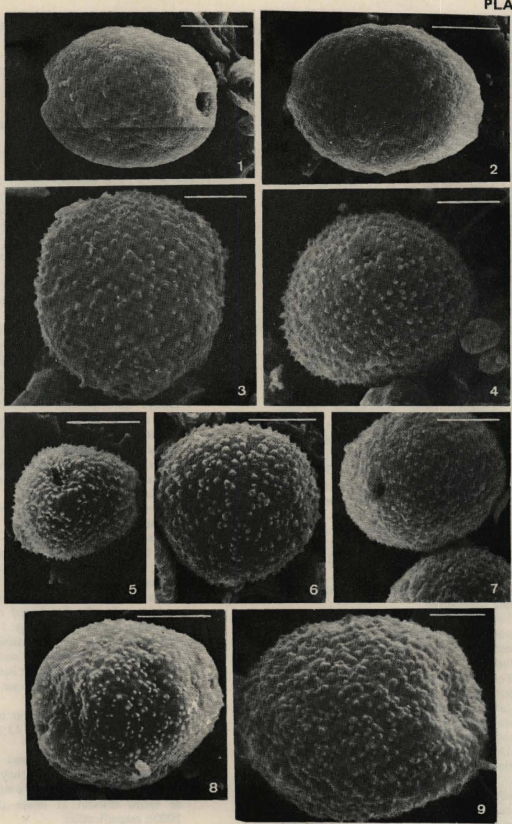

Plate I (har scale $=5 \mu \mathrm{m}$ )

Fig. 1 - Ficus insipids, finely undulate tectum. Fig. 2 - Ficus puichella, finely undulate tectum. Figs. 3, 4 Artocarpus heterophyllus, spinules and aperture. Fig. 5 - Batocarpus amazonicus. Fig. 6 - Castilla ulei. Fig. 7 Chlorophora tinctoria. Fig. 8 -Helicostylis tomentosa. Fig. 9-Pourouma acutiflora. 
"Barbosa Rodrigues" Herbarium, Itajai, Santa Catarina (HBR); and "Alberto Castellanos" Herbarium, Rio de Janeiro (GUA). The following specimens were observed by SEM: Acanthinophyllum ilicifolia (Spreng.) Burger, Sucre 5.287; Artocarpus heterophyllus Lamarck, Souza s.n.; Cannabis satwa L., Reitz and Klein 8.880; Bagassa tiliaefolia (Ham.) Benoist., Ducke on 01.08.1926; Batocarpus amazonicus (Ducke) Fosberg, Ducke 947; Brosimum discolor Schott ex Sprengel,'Klein 1.807; B. gucianense (Aubl.) Hub., Ducke on 30.01 .1933 ; B. lactescens (S. Moore) Berg, Reitz and Klein 212; Castilla ulei Warb., Ducke on 23.02.1932: Cecropia catarinensis Cuatrecasas, Hatschbach 5.103; C. glazioui Snethlage, Klein and Souza 7.329; C. obtusa Trécul, Reitz C-467; C. palmata Willdenow, Carauta 554 and 969A; Chlorophora tinctoria (L.) Gaud., Veloso 160 , P. da Silva $s / n$, October 1938, Rambo 38.604 and Reitz C-177; Clarisia racemosa R. et Pav., Duarte 5.969; Coussapoa schottii Miguel, Reitz 4.176; Dorstenia asaroides Gardner, Prance $s / n$, October 1973; D. brasiliensis Laur., Rambo $38.432 ;$ D. cayapia Vell., Carauta 1.408, Duarte 3.725 , Sucre $2.026 ; D$. morifolia Fisch. and Meyer, Carauta 1.878, Hatschbach 32.898; D. tenuis Bonpland, Smith and Klein 13.155, Smith and Klein $14.111 ; D$. sp., Emygdio 2.911 and Emmerich 3.457; Ficus insipida Willdenow, Reitz and Klein $2.290 ; F$. pulchella Schott ex Sprengel, Klein 1.807; Helicostylis tomentosa (P. et E.) Rusby, det.: W. Buerger; Maquiva calophylla (P. et E.) Berg, Ducke on 08.11.1932; Pereba tessmannii Macby, Ducke on 19.09.1931; Pourouma acutiflora Trécul, Klein 1.110; Pseudolmedia hietulla Kuhlm., Occhioni $s / n$; $P$. laevis (R. et P.) Macby, Ducke on 12.10.1913; Sorocea bonplandii (Baillon) Burger et al., Reitz and Klein 8.761.

For LM observations the pollen grains were acetolysed (ERDTMAN, 1952) and kept in glycerol; sometimes they were stained with basic fuchsin.

For SEM observations, acetolysed pollen sediment stored in glycerol or samples directly separated from the herbaria material, always suspended in $50 \%$ or $70 \%$ ethanol, were used. To remove the glycerol in the first case and the anther material in the second from the pollen grain surfaces a Bransonic B-12 ultra-sound apparatus or similar gave best results by a total application during 15 minutes, first in distilled water and then in ethanol; the pollen grain suspension was dropped onto SEM stubs and left to air-dry overnight at $37^{\circ} \mathrm{C}$, prior to sputtering with a $200 \AA$-thick gold layer in a Balzers-Union apparatus. The preparations were observed in a JEOL - $25 \mathrm{~S}-11 \mathrm{SEM}$ at magnifications up to $10,000 \mathrm{X}$.

\section{RESULTS}

Thirty-nine samples representing 19 gene$\mathrm{ra}$ and 30 species were observed by SEM. The following pollen surface patterns were distinguished:

1. The genus Ficus presents slightly irregular surfaces (Figs. 1 and 2) because of numerous very straight puncta in the tecta; there are no spinules or sca. brae.

2. Another configuration is represented by spinulous (scabrate) surfaces; the form, number and distribution of the spinules (scabrae) vary among the ge. nera:

a) They are of irregular sizes, not so numerous and irregularly dispersed over the pollen grain surfaces (Figs. $3-5$ ); their basal diameters may be as large as they are high and they always have pointed extremities. This surface pattern is observed in Acanthinophyllum ilicifolia, Artocarpus heterophyllus, Bagassa tiliaefolia, Batocarpus amazonicus, Coussapoa schottii, Maquiva calo. phylla and Pereba tessmannii.

b) The spinules are more numerous and smaller, but still irregularly distributed or clustered (Figs. 6-9) as in Castilla ulei, Chlorophora tinctoria, Helicostylis tomentosa and Pourouma acutiflora.

c) Numerous very fine spinules, more or less uniformly distributed over the pollen grain surfaces (Figs, $10-$ 12) occur in the genera Brosimum $(B$. discolor, $B$. guaianense and $B$. lactescens), Pseudolmedia ( $P$. hietul$l a$ and $P$. laevis) and Sorocea ( $S$. bonplandii).

d) Nearly verrucate grains occur only in Clarisia racemosa (Figs. 13 and 14).

e) Cannabis sativa (Figs. 15 and 16) has such fine spinules that they seem to be merely granula; the surface seems smooth at lower than $1000 \mathrm{x}$ magnification.

3. A especialized configuration is presented by the genus Cecropia. The spinules occur only at the equatorial regions 

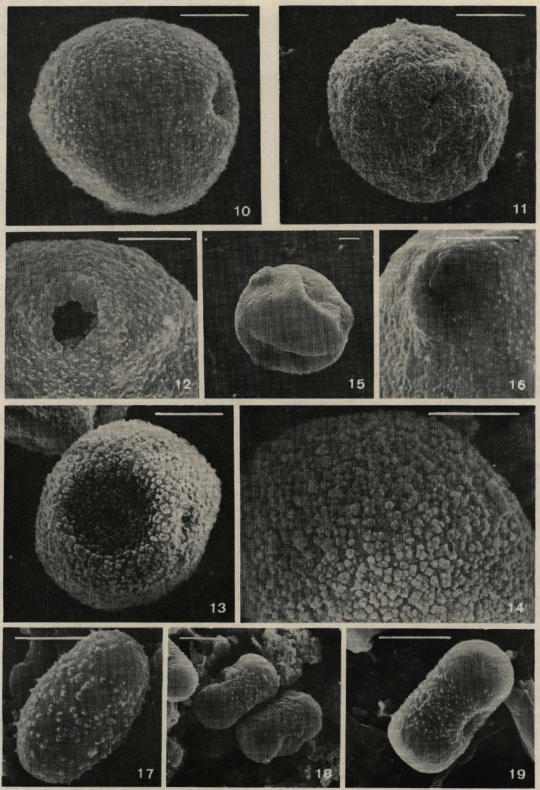

Plate II (bar scale $=5 \mu \mathrm{m}$ )

Fig. 10 - Brosimum lactescens, Fig. 11 - Pseudoimedia leevis, Fig. 12 - Sorocea bondplandii, spinules and aperture. Figs. 13, 14 - Clarisia racemosa. Figs. 15, 16 - Cannabis sativa, whole grain, spinules and aperture. Fig. 17 - Cecropia catarinensis. Fig: 18 - Cecropia obtusa, Fig. 19 -Cecropia palmata. 
of the grains and the apocolpia are smooth. Except for $C$, catarinensis (Fig. 17), with large spinules and reduced, smooth polar areas, the other examined species (C. glazioui, $C$. obtusa and $C$, palmata, Figs 18 and 19) have large polar areas and a well delimited spinulous, equatorial band.

4. The most specialized genus is Dorstenia (Figs, 20 and 21). The pantoporate surfaces of their grains are aspidote with smooth or spinulate annuli and spinulate or verrucate areas between the annuli and inside the pori. In some species the general surface appearance may be related to the age and the degree of distension of the grains (Figs. 22 and 23 ), so that the aspides are more or less protuberant.

\section{DISCUSSION}

A very fine punctate tectum occurs in the genus Ficus and may be considered as a basic structure. The species always seem to be smooth in LM observations (BARTH, 1976a; PALACIOS, 1968). Pollen grains like the Dorstenia type were presented as Ficus carica by TARNAVSCHI et al. (1967).

Another simple pollen grain surface pattern consists of irregularly scattered spinules (scabrae), sometimes with clustered spinules. The spinules are always visible in LM observations (STRAKA, 1966; BARTH et al., 1975; BARTH, 1976a). In order to divide such grains into pollen types, one has to utilize additional exine textures and aperture numbers, which will be commented upon in a future paper. Such a pollen grain surface is found in a great number of genera previously mentioned in this paper (sub-groups 2a and 2b); Acanthinophyllum ilicifolia pollen grains observed by SEM by NIEZGODA \& NOWACZYK (1976) and Bato. carpus amazonicus and Chlorophora tinctoria (PUNT \& EETGERINK, 1982) have the same pollen morphology as that observed here. The Brazilian species Bagassa guianensis examined by PUNT \& EETGERINK (1982) is also very similar to our investigated specimen; another Brazilian species that they examined, Maclura brasiliensis, seems to be close to our group $2 \mathrm{~b}$.

The number of spinules increases sequentially, while at the same time their dimensions decrease, until reaching a fine, regular spinulous surface as in Brosimum, Pseudolmedia and Sorocea. The spinule dimensions are at the LM resolution limit, so that sometimes the grains apper to be smooth (BARTH, 1976a; MELHEM, 1966; SALGADO-LABOURIAU, 1973; MAR. TINEZ-HERNANDEZ et al., 1979). For Sorocea bonplandii, the spinules are generally not clustered, as they are in $S$. guilleminiana and $S$. saxicola (NIEZGODA \& NOWACZYK, 1976), so that specific variations become evident at high magnifications.

The surface configuration of Clarisia racemosa is the same as that observed by NIEZGO. DA \& NOWACZYK (1976).

A different surface aspect is found in grains of Cecropia which, at the moment, apparently have no similarity with any other genus of this family. In LM, these grains generally appear smooth (BARTH, 1975), but SEM observations (BARTH, 1974) confirmed the equatorial band of spinules (ERDTMAN, 1952) also around the pori.

In Cannabis sativa the spinule distribution is less dense at the aperture areas; like the whole grain represented by SEM in HAMILTON (1976), the small scabrae are densely and uniformly distributed over the entire pollen grain surface. TARNAVSCHI et al. (1967) recognized by LM the finely granulate surface aspect for some parts of the grain, while MAKINO \& MELHEM (1973) describe them as smooth.

The grains of Dorstenia present peculiar, more or less spinulous, aspidote surface areas and spinulous or verrucate inter-aspide regions. A species-dependent number of pores is significant for their subdivision into sub-types and for determining their relationships (CARAUTA et al., 1979). A similar surface pattern was described by PUNT (1978) for this genus and for Scyphocyce; for Dorstenia by MELHEM (1966), SALGADO-LABOURIAU (1973), STRAKA (1966) and BARTH (1976a); for Dorstenia and Craterogyne by ERDTMAN (1952) and HAMILTON (1976).

As to the pollen types established by other authors and by detailed surface examination, the genus Ficus represents one pollen ty. pe, as in STRAKA (1966); Cannabis sativa occupies a particular position, also in STRAKA (1966) and HAMILTON (1976); Dorstenia differs from these, as does Cecropia as well; all the other genera may be included within a single pollen surface group having several sub-groups, like those here established under numbers $2 \mathrm{a}$-d. Thus, at the moment, one may recognize four pollen surface groups for Moraceae (excluding Cannabis sativa), some of which may be divided into sub groups.

With respect to the observations made by PUNT \& EETGERINK (1982) on pollen morphology of Moreae and from our own observa- 
PLATE III
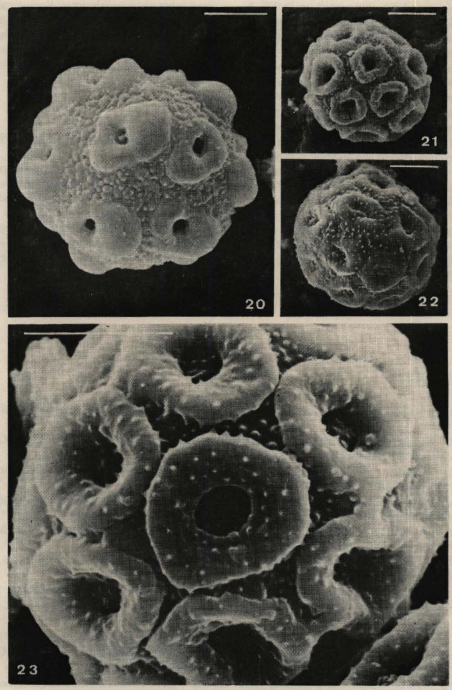

Plate III (bar scale $=5 \mu \mathrm{m})$

Fig. 20 -Dorstenia brasiliensis. Fig. 21 - Dorstenia tenuis. Figs. 22, 23 -Dorstenia sp., immature and mature pollen grains, respectively. 
tions, three pollen morphology groups occur in this tribe: the Artocarpus sub-group (2a) and the Chlorophora sub-group ( $2 \mathrm{~b}$ ), each containing numerous genera. The other is a monospecific pollen sub-group represented by Maclura pomifera from Kansas, USA, illustrated in PUNT \& EETGERINK (1982), which has some similarities with Cannabis sativa pollen grains (Figs. 15 and 16 and HAMILTON, 1976).

It is not possible to establish relationships within the Moraceae on the basis of surface characteristics only (BARTH, 1976b). There are apparent evolutionary trends, but it is difficult to establish their direction (BARTH, 1976a). To better understand the pollen relationships among the genera and/or the species, it is necessary to examine the exine texture. A first attempt using LM was made by BARTH (1976a), who indicated visible bacula for only some genera/species considered more evolved; for others, no bacula were recognized, so that more genera than those illustrated in MARTINEZHERNANDES et al. (1979) still need to be examined by TEM in the future.
Although the grains of the majority of the genera are small and 2-porate, the exine texture (BARTH, 1976a,b and MARTINEZ-HERNANDEZ et al., 1979) and the detailed surface patterns are so variable that the family may be considered as eurypalynous. Ecological and habitat specializations are indicated by the varied pollen grain morphologies, which, because of the tiny dimensions of their ornamentation, require further high resolution observations.

\section{ACKNOWLEDGEMENTS}

I gratefully acknowledge the Supervisory Staff of the Laboratory of Electron Microscopy. Biophysical Institute, Federal University of Rio de Janeiro, who permitted the use of their Scanning Electron Microscope, Ms. Maria da Penha $\mathrm{R}$, da Costa for the photographic reproduc. tions and Dr. T. Fairchild for manuscript revision.

\section{BIBLIOGRAPHY}

BARTH, O. M, - 1974 - O pólen de algumas especies de Cecropia (Moraceae). Leandra (UFRJ) III-IV (4-5) : $115-118$

BARTH, O, M. - 1976a - Catellogo Sistemático dos Polens das Plantas Arbóreas do Bresil Meridional. XXIII - Moreceae. Mem. Inst. Oswaldo Cruz 74(3-4):295-309.

BARTH, O. M. - $1976 \mathrm{~b}$ - Catalogo Sistemdtico dos Polens das Plantas Arbóreas do Brasil Meridional. XXIV Urticaceae. Mem. Inst. Oswaldo Cruz $74(3-4) ; 341-346$.

BARTH, O. M., MACIEIRA, E. G. \& CORTE-REAL, S, - 1975 - Morfologia do polen anemófilo e alergisante no Brasil. Casuarinaceae, Salicaceae, Moraceae, Ulmaceae e Urticaceae. Mem. Inst. Oswaldo Cruz, 73(3) : 141-152.

CARAUTA, J. P. P., VALENTE, M. da C. \& BARTH, O. M. - 1979 - Dorstenia L. (Moraceae). Notas Complemen. tares III. Arq. Jard. Bot., Rio de Janeiro XXIII : 105-113.

ERDTMAN, G. - 1952 - Pollen Morphology and Plant Taxonomy.Angiosperms. Chronica Botanica Co., Waltham, Mass., $539 \mathrm{p}$.

HAMILTON, A. C. - 1976 - Identification of East African Urticales pollen. Pollen et Spores XVIII (1) : 22-66.

HYDE, H. A. \& ADAMS, K. F. - 1958 - An Atlas of Airborne Pollen Grains, Macmillan and Co, Ltd., London, $112 \mathrm{p}$.

MAKINO, H. \& MELHEM, T. S. - 1973 - O polen de Cannabis sativa $L$, Ciéncia e Cultura 25 (6) :535-538.

MARTINEZ-HERNANDEZ, E., VARGAS-OLVERA, M. \& LUDLOW-WIECHERS, B., - 1979 - Ultraestructura de la exina en granos de polen en Angiospermas. Biotica 4 (1) :33-48.

MELHEM, T. S. - 1966 - Pollen Grains of Plants of the "Cernado", XII - Cucurbitaceae, Menispermaceae and Mo. raceae, An, Acad, brasil. Ciénc. 38 (1):195-203.

NAIR, P. K. K. \& SHARMA, M. - 1965 - Pollen morphological studies in Indian Urticales. Bot. Not. 118:177-186.

NIEZGODA, C.J. \& NOWACZYK, J. Jr, - 1976 - Palynological studies in Acanthinophyllum, Clarisia, Sorocea and Trophis (Moracease). Pollen et Spores XVIII (4): 513-522.

PALACIOS, Ch. R. - 1968 - Morfologia de los granos de polen de drboles del Estado de Morelos. Am. Esc. nac. Cienc. Biol, Mex., 16:41-169. 
PUNT, W. - 1978 - On the pollen morphology of Scyphosyce and Dorstenia (Moraceae). Grana 17: 77-79.

PUNT, W. \& EETGERINK, E. 1982 - On the pollen morphology of some genera of the tribe Moreae (Moraceae). Grana $21: 15-19$

RAMOS-ZAMORRA. D. - 1977 - Morfologia de los granos de polen de la familia Moraceae en Mexico. Bol. Soc. Bot. Mexico $36 \cdot 71-92$.

SAlgado-LABouriau, M. L. - 1973 - Contribuiçōo a Palinologia dos Cerrados. Acad. Brasil. Ciêne., Rio de Janeiro, $291 \mathrm{p}$.

STRAKA. H. - 1966 - Palynologia Madagassica et Mascarenica. Fam. 50.59 bis. Pollen et Spores VIII (2) :241-264.

TARNAVSCHI, I, T., SERBANESCU-JTARIU, S., MITROIU, N. \& RADULESCU, D. - 1967 - Zur Pollenmorphologie der Urticales aus der Flona Rumaniens. Rev. Roum. Biol. - Botanique $12(2-3): 251-262$. 